\title{
Consumer stated preferences for dairy products with carbon footprint labels in Italy
}

\author{
Maurizio Canavari ${ }^{1}$ and Silvia Coderoni ${ }^{2^{*}}$ (D)
}

\author{
*Correspondence: s.coderoni@ \\ univpm.it \\ ${ }^{2}$ Department of Economics and \\ Social Sciences, Università \\ Politecnica delle Marche, Piazzale \\ Martelli, 8, 60121 Ancona, Italy \\ Full list of author information is \\ available at the end of the article
}

\begin{abstract}
Carbon footprint (CF) labels on agri-food products represent one of the most important tools to convey information to consumers about the greenhouse gases emissions associated with their purchase behaviour.

Together with the growing interest of consumers in CF labels, the subject has gained attention also in the scientific literature, and formal evaluations of consumer response to carbon labelling have been published. Studies in this area aim at analysing consumers' preferences for buying products with a lower CF label or their willingness to pay (WTP) for these products.

The objective of this paper is twofold. First, the study proposes a review of the literature that so far has analysed consumer WTP for CF label, focusing on Italian consumers. Second, it uses the results of two surveys of consumers' attitudes towards dairy products with a lower CF label to analyse the factors determining a positive stated WTP. Results point out that a positive WTP for lower CF products is more likely to be declared by respondents who believe that buying products with less environmental impact can combat climate change. Conversely, highly pricesensitive consumers are less likely to be willing to pay more for CF-labelled products.
\end{abstract}

Keywords: Carbon footprint label, Environmental labels, Willingness to pay, Consumer preferences, Dairy products, Logistic regression

JEL codes: D12, Q54, Q01

\section{Introduction}

Climate change mitigation is one of the key environmental goals of agricultural production worldwide (Gerber et al. 2013). Moreover, in Europe, climate change mitigation objectives and the contribution that agriculture is expected to provide have reached the top of the political agenda (European Commission 2016). Climate action is one of the main priorities of the Common Agricultural Policy (CAP) and agricultural greenhouse gases (GHG) emissions' mitigation has become both an objective of the new architecture of the first pillar payments and a focus area of the actual Rural Development Policy programming period (Council of the European Union 2013a, 2013b).

According to many studies in this field, however, supply-side options alone, i.e. options that tackle production aspects of GHG mitigation, are not sufficient to reach the ambitious mitigation targets set by European and international climate policy agenda

(c) The Author(s). 2020 Open Access This article is distributed under the terms of the Creative Commons Attribution 4.0 International License (http://creativecommons.org/licenses/by/4.0/), which permits unrestricted use, distribution, and reproduction in any medium, provided you give appropriate credit to the original author(s) and the source, provide a link to the Creative Commons license, and indicate if changes were made. 
(European Commission 2011, 2016). In addition, though the most cost-effective ways to reduce GHG are carbon taxes and cap and trade systems (Nordhaus 2013; Stern 2007), these economic instruments are unlikely to be implemented in the near future in the agricultural sector, both in the EU (Coderoni and Esposti 2018) and in the United States (Shewmake et al. 2015). Thus, demand-side solutions to climate change, which consist of more sustainable consumption patterns, are becoming important tools to curb agricultural GHG emissions (Garnett 2011; Bajželj et al. 2014; Armel et al. 2011; Brunelle et al. 2017; Creutzig et al. 2016; de Boer et al. 2016).

In this respect, the so-called "sustainable labels", i.e. types of labels that are designed to convey to the consumer concepts related to all the facets of sustainability, are the most common tools supporting changes in consumption patterns (Vermeir and Verbeke 2006; Zander and Hamm 2010). When sustainable labels try to show to consumers the overall impact of the product converting it into a standardised measure of carbon dioxide emissions, they are referred to as "carbon footprint" (CF) labels. CF labels in practice indicate the quantity (in grams) of carbon dioxide equivalent $\left(\mathrm{CO}_{2 \mathrm{e}}\right)^{1}$ emitted into the atmosphere throughout all the life cycle of a product or service, which comprises production, transport, transformation, distribution and purchase (Sander et al. 2016). The rationale for these labels, when applied to food products, is that they may help to orient the consumer towards buying more GHG saving agricultural products and thus mitigating agriculture's contribution to global warming.

Despite the potentially relevant role of demand-side options in tackling climate change, there have been a few consumer studies on WTP for carbon footprint labels (Hoek et al. 2017), especially for Italian agriculture, where the bulk of the empirical literature has focussed on the potential and effectual role of the production processes to mitigate agricultural GHG emissions. ${ }^{2}$ Thus, it would be essential to analyse consumers' preferences for purchasing products with a label showing a lower CF, to understand what drives their choices, and to recognise to what extent there is a mitigation potential deriving from Italian consumers' choices for the Italian agricultural sector.

In this context, the objective of this paper is twofold. First, we review the literature that until 2018 has analysed consumer preferences and WTP for CF label, with a focus on Italian consumers. Second, we illustrate some of the results of two separate pilot surveys aimed at detecting whether consumers state a positive WTP for dairy products with a CF label.

The remainder of the paper is structured as follows: Section 2 introduces some definition of sustainable labels, specifically referring to CF; Section 3 presents the literature review; Section 4 shows the case studies analysed, while Section 5 presents and discusses the results of the analysis; Section 6 finally proposes some concluding policy remarks and future research guidelines.

${ }^{1} \mathrm{CO}_{2 \mathrm{e}}$ is a term that describes different greenhouse gases in a common unit. A quantity of non- $\mathrm{CO}_{2} \mathrm{GHG}$ (i.e. methane or nitrous oxide) can be expressed as $\mathrm{CO}_{2 \mathrm{e}}$ by multiplying the amount of the GHG by its global warming potential (GWP).

${ }^{2}$ For Italian agriculture case study, both micro and macro level have been explored (see among others: Rete Rurale Nazionale 2012; Coderoni and Esposti 2014; Baldoni et al. 2017, 2018). 


\section{Carbon footprint labels in the agri-food sector}

According to Miranda-Ackerman and Azzaro-Pantel (2017), "New consumer awareness is shifting industry towards more sustainable practices, creating a virtuous cycle between producers and consumers enabled by eco-labelling".

This consumer awareness is the foundation of sustainable consumption, which is grounded in a decision-making process that takes into account not only individual needs and wants, but also their social responsibility. In fact, as De Pelsmacker et al. (2005) have found, when dealing with sustainability concerns, an important driver for change is the inclination of the "ethical consumer [that] feels responsible towards society and expresses these feelings by means of his purchase behaviour". ${ }^{3}$

The concept of sustainability has deeply evolved from the primer environmentalist approach (Kumar et al. 2012) and now it comprises, in its most widespread use, three different aspects: the economic, the environmental and the social one (Vermeir and Verbeke 2006). Sustainable products are those products whose characteristics respect one or more of these aspects (Vackier et al. 2002).

Eco-labelling, or environmentally sustainable labels, are a means to inform consumers of the environmental performance of either the products or the production systems they come from, and they can also inform the consumer on measures taken by the producers to minimise the product's environmental impact.

One particular type of sustainable label is the so-called CF label, which is an indicator of the total amount of $\mathrm{CO}_{2}$, or the equivalent of $\mathrm{CO}_{2}$ in the case of the emission of other GHG (usually expressed in grams), emitted into the atmosphere along the whole "life cycle" of a particular product or service. Thus, the calculation comprises not only production but also transport, transformation, distribution, use and disposal.

In the agri-food sector, the European Commission has identified 129 (both public and private) information plans concerning the concept of sustainability (Grunert et al. 2014). Among these labels, the organic brand (referred to also as "bio") is the most widely used in the Italian market. Local production, however, is gaining popularity among Italian consumers, even though a universal label for the definition of such products has not yet been established (Bazzani and Canavari 2013, 2017).

CF labels are rarely present in the agri-food market ${ }^{4}$, and only recently, consumers have occasionally had access to information about the CF of products, both in Italy and in most European countries. Tesco experience is exemplary in this field: the retailer, together with the Carbon Trust, has started introducing the first CF label in food retailing in 2009, claiming that they would have labelled all the 50,000 own-brand products (The Economist 2011). However, in 2012, when they only have been able to label 500 products, they had to give up the project. The reasons for this failure were that: consumers found the labels complicated and difficult to understand (so the company was looking for alternatives to replace the $\mathrm{CF}$ ); the process of labelling the products revealed much more time consuming than planned and other retailers were slow in

\footnotetext{
${ }^{3}$ Nevertheless, studies have found that convenience, value for money, habit, personal health concerns, hedonism and individual responses to social and institutional norms are still relevant aspects driving everyday consumption practices (SDC 2003).

${ }^{4}$ Instead, for other products (like home appliances, paper products, detergents, etc.), there is abundance of eco-labelling initiatives.
} 
adopting CF labelling. Thus, the uptake of the label could not reach the desired critical mass (Financial Times 2012).

Nowadays, there are only a few CF labels that have continued in the marketplace. However, as mentioned by Peschel et al. (2016) and Grebitus et al. (2015), Eurobarometer survey's results have found $72 \%$ of EU citizens agreeing that CF information on products should be mandatory (European Commission 2009). More recently, about $90 \%$ of EU citizens have declared that buying environmentally friendly products can bring real benefits to the environment (European Commission 2012).

In this context, it should be of much interest to investigate the drivers and the socioeconomic characteristics of respondents that can influence a positive WTP of consumers towards CF-labelled products.

\section{A literature review of WTP studies on CF for food products}

Consumers' preferences for lower CF label products have not yet been widely explored in the literature (Vanclay et al. 2011), also because of scarce market presence and uptake, and only recently, there has been a growing body of literature proposing formal evaluations of consumer response to carbon labelling. ${ }^{5}$

We performed a literature review to examine the works available in the Italian and international scientific literature that so far have analysed consumer preferences and WTP for CF label. ${ }^{6}$

Articles were selected by checking against pre-determined criteria for eligibility and relevance. Firstly, the following keywords have been identified: "footprint" (and its possible variation "foot-print"), "consumer", "food", together with their Italian translations. Secondly, a search for the abstracts of the articles has been done based on these keywords in the primary databases for scientific relevant literature (Scopus, Web of Knowledge, AgEconSearch, EconPapers), and thus pertinent articles have been selected. ${ }^{7}$

Approximately 300 articles have been consulted (including 150 references from Scopus and 130 from the Web of Knowledge, largely overlapping). Those papers went through a screening process that made emerge only 27 of them for an in-depth analysis, as they were in line with the specific goals of the review. These low figures reinforce the argument that the topic has not been widely explored in the empirical literature so far, in particular for the Italian consumers. Table 1 summarises the main aspects of the selected studies: country, products of reference, the methodology used and the main findings.

Most of these studies show that in general consumers are responsive to CF on different products indicating lower emissions, than conventional ones. However, as Vanclay et al. (2011) found, CF labels are most effective when combined with lower prices.

\footnotetext{
${ }^{5}$ The most recent literature on the evaluation of consumer preferences for sustainable food, is focusing on a more comprehensive evaluation of the environmental impact of production that encompasses different resources exploited by agricultural activities (Steiner et al. 2017; Grebitus et al. 2016; Grunert et al. 2014). Some of these recent works have been included in the present analyses, however, only the results regarding consumers' preference for CF labels are reported, in line with the objectives of the study.

${ }^{6}$ This literature review is an update until early 2018 of the review performed by Canavari and Bazzani (2016), which covers articles published until 2014. For more details on methodological aspects related to some of the cited papers, the reader can refer to the aforementioned work.

${ }^{7} \mathrm{We}$ acknowledge that the criteria used for the selection of the papers might have caused the exclusion of some important works on the topic analysed. Thus, the literature review has also considered papers that were cited by the ones selected, even if they did not contain the chosen keywords, to allow a more comprehensive analysis of the phenomenon.
} 
Table 1 Published articles regarding WTP evaluations for CF labels: country, products of reference, methodology used and main findings

\begin{tabular}{|c|c|c|c|c|}
\hline Citation & Product & Country & Methods & Main findings \\
\hline $\begin{array}{l}\text { Akaichi et al. } \\
2013\end{array}$ & Rice & USA & EA & $\begin{array}{l}\text { WTP } 22 \% \text { higher when giving information } \\
\text { about local origin or lower CF }\end{array}$ \\
\hline $\begin{array}{l}\text { Akaichi et al. } \\
2016\end{array}$ & Banana & $\begin{array}{l}\text { Scotland, The } \\
\text { Netherlands, France }\end{array}$ & DCE & $\begin{array}{l}\text { Positive WTP for bananas with lower CF } \\
\text { combined with other aspects (fair trade } \\
\text { and organic) }\end{array}$ \\
\hline $\begin{array}{l}\text { Caputo et al. } \\
2012\end{array}$ & Tomato & Italy & DCE & $\begin{array}{l}\text { Positive propensity to purchase products } \\
\text { labelled with low CF }\end{array}$ \\
\hline $\begin{array}{l}\text { Caputo et al. } \\
2013 a\end{array}$ & Tomato & USA & DCE & $\begin{array}{l}\text { Avg. WTP for low transport CF ranging } \\
\text { from } 0.31 € \text { to } 3.13 € \text { depending on the } \\
\text { latent class }\end{array}$ \\
\hline $\begin{array}{l}\text { Caputo et al. } \\
2013 \mathrm{~b}\end{array}$ & Tomato & Italy & DCE & Avg. WTP for low transport CF: $0.76 €$ \\
\hline $\begin{array}{l}\text { Chen et al. } \\
2017\end{array}$ & $\begin{array}{l}\text { Purified } \\
\text { bottled } \\
\text { water }\end{array}$ & China & EA & $\begin{array}{l}\text { Avg. premium price of } 0.274 \mathrm{RMB} \text { for } \\
\text { purified water with CF label }\end{array}$ \\
\hline $\begin{array}{l}\text { Colantuoni } \\
\text { et al. } 2016\end{array}$ & Potato & Germany and Italy & DCE & $\begin{array}{l}\text { Both Germans and Italians were unwilling } \\
\text { to pay more for CF certification. (avg. } \\
\text { marginal WTP estimates for the attribute } \\
\text { CF were negative, }-0.13 € / \mathrm{kg} \text { for German } \\
\text { and }-0.41 € / \mathrm{kg} \text { for Italian respondents) }\end{array}$ \\
\hline $\begin{array}{l}\text { Drichoutis } \\
\text { et al. } 2016\end{array}$ & $\begin{array}{l}\text { Eggs, olive } \\
\text { oil }\end{array}$ & Greece & $\begin{array}{l}\text { Inferred and } \\
\text { CV }\end{array}$ & $\begin{array}{l}\text { WTP premiums for carbon neutral label of } \\
\text { up to } 28 \% \text { for eggs and } 23 \% \text { for olive oil }\end{array}$ \\
\hline $\begin{array}{l}\text { Echeverría } \\
\text { et al. } 2014\end{array}$ & $\begin{array}{l}\text { Milk and } \\
\text { bread }\end{array}$ & Chile & CV & $\begin{array}{l}\text { Avg. WTP for low CF: } 29 \% \text { more for milk } \\
\text { and } 10 \% \text { more for bread }\end{array}$ \\
\hline $\begin{array}{l}\text { Grebitus } \\
\text { et al. } 2012\end{array}$ & Meat & Canada & DCE & $\begin{array}{l}\text { WTP not estimated. The presence of } \\
\text { information about a higher CF reduces } \\
\text { the likelihood of choice }\end{array}$ \\
\hline $\begin{array}{l}\text { Grebitus } \\
\text { et al. } 2015\end{array}$ & Potato & Germany & DCE & $\begin{array}{l}\text { WTP not estimated. Overall respondents } \\
\text { tend to buy products with CF label }\end{array}$ \\
\hline $\begin{array}{l}\text { Grebitus } \\
\text { et al. } 2016\end{array}$ & $\begin{array}{l}\text { Beef, } \\
\text { yoghurt, } \\
\text { potatoes }\end{array}$ & Canada and Germany & DCE & $\begin{array}{l}\text { Respondents are willing to choose } \\
\text { products with higher } \mathrm{CF} \text { if compensated } \\
\text { by discounted prices: Germans most } \\
\text { discount potatoes }\left(-1.45 € / \mathrm{Kg} \text { of } \mathrm{CO}_{2}\right) \text {, } \\
\text { yoghurt (-0.73€) and ground beef }(-0.23 \\
€) \text {; Canadians most discounts yoghurt } \\
\text { (Canadian } \$-0.66) \text {, potatoes (Canadian } \$ \\
-0.46) \text {, and ground beef (Canadian } \$ \\
-0.11 \text { ). }\end{array}$ \\
\hline $\begin{array}{l}\text { Hoek et al. } \\
2017\end{array}$ & $\begin{array}{l}\text { Rice, meat, } \\
\text { tomato }\end{array}$ & Australia & DCE & $\begin{array}{l}\text { WTP not estimated. The combination of a } \\
\text { health and environmental logo have a } \\
\text { more positive effect than the logos } \\
\text { separately or no logo. }\end{array}$ \\
\hline $\begin{array}{l}\text { Kimura et al. } \\
2010\end{array}$ & $\begin{array}{l}\text { Chocolate } \\
\text { bar, chips, } \\
\text { candy, juice }\end{array}$ & Japan & DCE & $\begin{array}{l}\text { WTP in the read-only condition is smaller } \\
\text { (from } 127 \text { to } 167 \text { yen) than that in the } \\
\text { active-search condition (from } 103 \text { to } 196 \\
\text { yen) }\end{array}$ \\
\hline $\begin{array}{l}\text { Koistinen } \\
\text { et al. } 2013\end{array}$ & $\begin{array}{l}\text { Minced } \\
\text { meat }\end{array}$ & Finland & DCE & $\begin{array}{l}\text { WTP for beef }=24.50 € / \mathrm{kg} \text {; lower WTP of } \\
1.6 \% \text { for beef with information on CF WTP } \\
\text { for beef }=23.65 € / \mathrm{kg} \text {; WTP greater than } \\
2.2 \% \text { for pig meat with information on CF }\end{array}$ \\
\hline Li et al. 2016 & Beef & US & DCE & $\begin{array}{l}\text { Avg. WTP } \$ 306 \text { among consumers } \\
\text { supporting a hypothetic "Raised Carbon } \\
\text { Friendly" beef certification program and } \\
\$ 64 \text { among all beef-consuming } \\
\text { households }\end{array}$ \\
\hline $\begin{array}{l}\text { Lombardi } \\
\text { et al. } 2017\end{array}$ & Milk & Italy & DCE & $\begin{array}{l}\text { Avg. price premium for CF labelling } \\
\text { is } 0.55 €\end{array}$ \\
\hline Michaud & Flowers & France & Non- & Premium eco-label: $1.73 € /$ piece \\
\hline
\end{tabular}


Table 1 Published articles regarding WTP evaluations for CF labels: country, products of reference, methodology used and main findings (Continued)

\begin{tabular}{|c|c|c|c|c|}
\hline Citation & Product & Country & Methods & Main findings \\
\hline et al. 2012 & & & $\begin{array}{l}\text { hypothetical } \\
\text { DCE }\end{array}$ & Premium low CF: 4.09€/piece \\
\hline $\begin{array}{l}\text { Mostafa } \\
2016\end{array}$ & $\begin{array}{l}\text { Not } \\
\text { specified }\end{array}$ & Egypt & DCE & $\begin{array}{l}\text { Premium price of } 75 \text { up to } 90 \text { Egyptian } \\
\text { pounds (EP) for carbon-labelled products } \\
\text { depending on the evaluation technique }\end{array}$ \\
\hline $\begin{array}{l}\text { Mueller- } \\
\text { Loose and } \\
\text { Remaud, } \\
2013\end{array}$ & Wine & $\begin{array}{l}\text { UK, France, Germany, } \\
\text { US East Coast, US } \\
\text { Midwest, Anglophone } \\
\text { Francophone Canada }\end{array}$ & DCE & $\begin{array}{l}\text { Premium for "Carbon Zero" label: UK = } \\
0.20 £ ; \text { France }=-0.24 € ; \text { Germany }=-0.02 € ; \\
\text { US East Coast }=1.02 \$ ; \text { US West Coast }= \\
0.53 \$ ; \text { USA Midwest = 0.44\$; Anglophone } \\
\text { Canada }=0.36 \$\end{array}$ \\
\hline $\begin{array}{l}\text { Onozaka } \\
\text { and } \\
\text { Mcfadden } \\
2011\end{array}$ & $\begin{array}{l}\text { Apple and } \\
\text { tomato }\end{array}$ & USA & DCE & $\begin{array}{l}\text { Negative WTP for products with a CF } \\
\text { higher than } 10 \% \text { : }-0.01 \text { for apples and } \\
-0.02 \text { for tomatoes (in } \$ \text { per pound) }\end{array}$ \\
\hline $\begin{array}{l}\text { Steiner et al. } \\
2017\end{array}$ & Yoghurt & Germany & DCE & $\begin{array}{l}\text { WTP not estimated. The presence of } \\
\text { information about a lower CF slightly } \\
\text { increases the utility of the "ecologically } \\
\text { oriented" group of respondents }\end{array}$ \\
\hline $\begin{array}{l}\text { Van Loo } \\
\text { et al. } 2014\end{array}$ & $\begin{array}{l}\text { Chicken } \\
\text { breast }\end{array}$ & Belgium & DCE & $\begin{array}{l}\text { Premium price of } 18 \% \text { and } 24 \% \\
\text { respectively for the } 20 \% \text { and } 30 \% \mathrm{CO}_{2^{-}} \\
\text {reduction, for the low-income group }\end{array}$ \\
\hline $\begin{array}{l}\text { Van Loo } \\
\text { et al. } 2015\end{array}$ & Coffee & Northwest Arkansas & CE & $\begin{array}{l}\text { No significant premium price for the } \\
\text { Carbon Footprint label }\end{array}$ \\
\hline $\begin{array}{l}\text { Vecchio } \\
2013\end{array}$ & Wine & Italy & EA & $\begin{array}{l}\text { Avg. WTP for low CF wine: } 3.24 € \text { (avg. } \\
\text { WTP for conventional wine: } 2.50 € \text { ) }\end{array}$ \\
\hline $\begin{array}{l}\text { Vecchio and } \\
\text { Annunziata } \\
2015\end{array}$ & $\begin{array}{l}\text { Chocolate } \\
\text { bars }\end{array}$ & Italy & EA & $\begin{array}{l}\text { Avg. WTP } 1.41 € \text { for CF labelled bar. Factors } \\
\text { affecting WTP for CF label: young } \\
\text { individuals express a } 10 \% \text { higher WTP; } \\
\text { female respondents: } 9 \text { cents more; } \\
\text { intensity of trust in the specific labels: } 16 \\
\text { cents more }\end{array}$ \\
\hline
\end{tabular}

EA Experimental auctions, DCE Discrete choice experiment, CV Contingent valuation

Moreover, Akaichi et al. (2013) and Onozaka and Mcfadden (2011) highlighted that consumers have been particularly likely to buying low- $\mathrm{CO}_{2}$ products in case they were also labelled with local origin, and according to Hoek et al. (2017), the combination of a health and carbon logo has a more positive effect than the logos separately or no logo. An interesting result is that from Shewmake et al. (2015) that have shown how even if CF labels can lower GHG emissions, they can also have the potential to incur in the opposite effect if their implementation does not account for consumer beliefs as well as complementary and substitute relationships among different products.

Among the sorted articles, only the works by Caputo and co-authors (Caputo et al. 2012, 2013b), Vecchio (2013), Vecchio and Annunziata (2015), Lombardi et al. (2017) and Colantuoni et al. (2016) focused specifically on the Italian market.

Caputo et al. (2012) provided information on the presence of food miles' labels and the level of GHG emissions related to transport, finding a positive influence of both information on consumers' utility. Caputo et al. (2013b) found that Neapolitan consumers interviewed have shown a greater WTP for transport distance information label (food miles) rather than for the more comprehensive CF label. This finding suggests that the local origin of the product might have an impact on the Italian consumers' purchasing choice. Italian consumers could thus be more concerned with labels related to a concept of sustainability together with the local origin. 
Vecchio (2013) and Vecchio and Annunziata (2015) evaluate young consumers' attitude towards sustainability labels. Vecchio (2013) found a positive young adult wine drinkers' WTP for CF-labelled wine. Vecchio and Annunziata (2015) found a positive (1.41€) WTP for CF-labelled chocolate bars and identified some factors positively affecting WTP for CF label: age (younger individuals express a higher WTP); gender (female respondents); intensity of trust in the specific labels and the preference for food obtained in an environmentally friendly way.

Lombardi et al. (2017) analyse consumers' preferences when buying fresh milk and find an average premium price of $0.55 €$ per litre.

On the contrary, Colantuoni et al. (2016) explore the market potential of domestic early potato and find that Italian (and German) respondents were unwilling to pay more for CF certification. Marginal WTP estimated was, in fact, negative and higher for Italians than for Germans.

As regards the type of product, the preference for low CF product has been found for both livestock and vegetable foodstuff. Echeverría et al. (2014) have analysed the WTP of Chilean consumers for both a product of vegetable origin (bread) and an animal product (milk) and found that respondents showed greater sensitivity when evaluating animal products as they were more likely to pay for lower CF for milk than for bread. To this respect, product origin (animal or vegetal) can be acknowledged as an additional aspect that could potentially affect the preferences of Italian consumers for CF labels: e.g. Canavari and Nayga (2009) have shown that Italian consumers exhibit differentiated behaviours when consumer choice is related to GMO products of vegetable origin rather than of animal origin.

As regards the methodological aspect, the WTP for low CF products was primarily estimated by hypothetical choice experiments. Only five studies out of 27 have used non-hypothetical methods (i.e. experimental auctions in four cases and a real choice experiment in one case).

\section{The two case studies in the dairy sector: data and method}

The two case studies carried out dealt with consumers' habits related to dairy foodstuffs purchasing and were performed through two different surveys aimed at evaluating consumer understanding, knowledge, and preference for low CF products. Besides, they aimed at identifying the products' characteristics that influence purchasing behaviour and the consumers' WTP for the purchase of 1 litre of fresh milk with a lower CF label in comparison to a conventional one. The focus on dairy foodstuff was driven by the importance of livestock products in the debate at international level for their higher contribution to climate change with respect to vegetable foodstuff production (Gerber et al. 2013; GRAIN and IATP 2018).

The two studies were conducted among Italian consumers from December 2016 to February 2017, in both cases using an online questionnaire gathering information on consumption choices and socio-economic characteristics for 393 consumers interviewed (215 in case study A and 178 in case study B, respectively). The questionnaires were similar but not identical, and they were composed of four sections: the first on consumers' habits, the second on their environmental awareness, the third about their knowledge of environmental and CF labels, and a section dealing with personal sociodemographic information (Author1 et al. 2018). 
Though the use of web instruments to administer the questionnaire has facilitated reaching a high number of respondents, it raises the issue of representativeness of the sample, because this sampling method tends to gather self-selected respondents. Consequently, it usually generates a biased sample, in which younger people with a higher level of education or web literacy are overrepresented (Canavari et al. 2005). Therefore, the samples cannot be considered representative of Italian consumers; nevertheless, they allow obtaining quite interesting information about the relationship among the variables analysed. Though WTP estimations based on a non-representative sample cannot be used to extend WTP results to the population analysed, as figures would be biased, the relationships among the socio-economic characteristics of respondents the positive WTP eventually expressed, remain valid.

Table 2 and Table 3 show the descriptive statistics of the surveys analysed. As mentioned, the questionnaires were similar, but not identical. Thus, Table 2 shows the replies to the question that differed among surveys, while Table 3 shows only the shared items analysed.

As regards methodological aspects, WTP analysis was conducted with different approaches, both relying on the contingent evaluation $(\mathrm{CV})$ method. $\mathrm{CV}$ is a method of estimating the value that a respondent gives to a specific good or a good attribute, by asking to directly report his WTP, rather than inferring it from observed behaviours in market transactions. For this reason, CV is often referred to as a "stated preference" method, on opposite to "revealed preference" method based on existing prices. There are different CV approaches that depend on the way consumers are asked about their preferences. In the present analysis, in the case of study A, the survey used the open-ended contingent valuation method that relies upon asking directly to consumers to state their WTP for the product considered. An open-ended question is a question that is designed to encourage a full, meaningful answer, using the subject's personal knowledge or feelings. In the case of study B, we relied upon a dichotomous choice contingent valuation: a hypothetical purchase situation has been proposed to estimate the WTP, by comparing product 1 (milk bottle with $200 \mathrm{~g}$ of $\mathrm{CO}_{2 \mathrm{e}}$ emissions) at the fixed price of $1.30 €$ with product 2 (bottle of milk with $150 \mathrm{~g}$ of $\mathrm{CO}_{2 \mathrm{e}}$ emissions). Respondents were asked to state their preference between the two products according to a price variation of $0.10 €$ of product 2 , up to a maximum value of $2.00 €$. Given these different approaches for the elicitation of the WTP in the two studies, the consumer's preference has been evaluated considering whether the choice of the respondent (individual outcome variable) was to state a positive WTP for lower CF products or not. The dichotomous choice contingent valuation, proposing such a take-it-or-leave-it survey valuation question, is more likely to reflect real individual purchase decisions. Moreover, such elicitation format has shown to be less susceptible to strategic bidding behaviour than the open-ended one.

A conditional logit model has been estimated to investigate the determinants of the probability for consumers to declare a positive WTP for products with lower CF, based on explanatory variables, as responses shared to both surveys, expressing some sociodemographic characteristics and attitudes of the consumers interviewed. The general equation for the conditional logit model estimated is:

$$
P_{i}\left(y_{i} \neq 0 \mid X_{i}\right)=\frac{\exp \left(X_{i} \beta\right)}{1+\exp \left(X_{i} \beta\right)}
$$

where $i$ indicates the generic individual; $P_{i}$ is the predicted probability of individual $i$ to make a specific choice; $\beta$ is a vector of unknown parameters and $X$ a vector of 
Table 2 Descriptive statistics of the questions differing between the two surveys

\begin{tabular}{|c|c|c|c|c|c|}
\hline Variable & $\begin{array}{l}\text { Type of } \\
\text { variable }\end{array}$ & Obs. & Description & $\begin{array}{l}\text { Possible } \\
\text { values }\end{array}$ & Mean \\
\hline \multicolumn{6}{|l|}{ Survey A } \\
\hline Knows CC & Binary & 215 & If the respondent knows climate change phenomenon & Yes (1) No (0) & 0.99 \\
\hline $\begin{array}{l}\text { Interest in } \\
\text { CC }\end{array}$ & Ordered & 215 & If is interested in climate change & From 1 to 5 & 3.92 \\
\hline Recycle & Ordered & 215 & $\begin{array}{l}\text { If thinks that recycling products helps mitigating climate } \\
\text { change }\end{array}$ & From 1 to 5 & 4.01 \\
\hline Label & Ordered & 215 & $\begin{array}{l}\text { If thinks that the consumption of products with an } \\
\text { environmental label helps mitigating climate change }\end{array}$ & From 1 to 5 & 3.23 \\
\hline Trust & Ordered & 215 & $\begin{array}{l}\text { If gives importance to trust in the retailer when buying a } \\
\text { food product }\end{array}$ & From 1 to 5 & 3.37 \\
\hline $\begin{array}{l}\text { Nutritional } \\
\text { information }\end{array}$ & Ordered & 215 & $\begin{array}{l}\text { If gives importance to nutritional information when } \\
\text { buying a food product }\end{array}$ & From 1 to 5 & 3.52 \\
\hline $\begin{array}{l}\text { CF label } \\
\text { valuation }\end{array}$ & Ordered & 215 & How clear evaluates the information on the CF label & From 1 to 5 & 2.46 \\
\hline WTP & Continuous & 215 & $\begin{array}{l}\text { Premium price (\%) that is available to pay for lower CF } \\
\text { products }\end{array}$ & From 1 to 5 & 0.06 \\
\hline Web tool & Ordered & 215 & $\begin{array}{l}\text { If thinks that the web tools can help promoting } \\
\text { knowledge and dissemination of CF labels }\end{array}$ & From 1 to 5 & 4.10 \\
\hline $\begin{array}{l}\text { Advertising } \\
\text { tool }\end{array}$ & Ordered & 215 & $\begin{array}{l}\text { If thinks that advertising can help promoting knowledge } \\
\text { and dissemination of CF labels }\end{array}$ & From 1 to 5 & 3.53 \\
\hline $\begin{array}{l}\text { Education } \\
\text { tool }\end{array}$ & Ordered & 215 & $\begin{array}{l}\text { If thinks that education can help promoting knowledge } \\
\text { and dissemination of CF labels }\end{array}$ & From 1 to 5 & 4.09 \\
\hline $\begin{array}{l}\text { Campaigns } \\
\text { tool }\end{array}$ & Ordered & 215 & $\begin{array}{l}\text { If thinks that campaigns can help promoting knowledge } \\
\text { and dissemination of CF labels }\end{array}$ & From 1 to 5 & 3.65 \\
\hline Label tool & Ordered & 215 & $\begin{array}{l}\text { If thinks that labels can help promoting knowledge and } \\
\text { dissemination of CF labels }\end{array}$ & From 1 to 5 & 3.46 \\
\hline $\begin{array}{l}\text { Newspapers } \\
\text { tool }\end{array}$ & Ordered & 215 & $\begin{array}{l}\text { If thinks that newspapers can help promoting } \\
\text { knowledge and dissemination of CF labels }\end{array}$ & From 1 to 5 & 3.05 \\
\hline \multicolumn{6}{|l|}{ Survey B } \\
\hline Shops & Ordered & 178 & If does food shopping for the family & $\begin{array}{l}\text { From } 1 \\
\text { (always) to } 4 \\
\text { (never) }\end{array}$ & 2.39 \\
\hline Label & Ordered & 178 & If reads food labeling before buying & From 1 to 4 & 1.99 \\
\hline $\begin{array}{l}\text { Shop } \\
\text { frequency }\end{array}$ & Ordered & 178 & How many times per week does food shop & From 1 to 3 & 1.75 \\
\hline $\begin{array}{l}\text { Sensory } \\
\text { quality }\end{array}$ & Ordered & 178 & $\begin{array}{l}\text { If gives attention to sensory quality when choosing a } \\
\text { dairy product at the supermarket }\end{array}$ & From 1 to 5 & 3.72 \\
\hline Discounts & Ordered & 178 & $\begin{array}{l}\text { If gives attention to discounts when choosing a dairy } \\
\text { product at the supermarket }\end{array}$ & From 1 to 5 & 2.97 \\
\hline Aesthetics & Ordered & 178 & $\begin{array}{l}\text { If gives attention to aesthetics when choosing a dairy } \\
\text { product at the supermarket }\end{array}$ & From 1 to 5 & 2.21 \\
\hline $\begin{array}{l}\text { Expiration } \\
\text { date }\end{array}$ & Ordered & 178 & $\begin{array}{l}\text { If gives attention to expiration date when choosing a } \\
\text { dairy product at the supermarket }\end{array}$ & From 1 to 5 & 3.88 \\
\hline Certification & Ordered & 178 & $\begin{array}{l}\text { If gives attention to certification when choosing a dairy } \\
\text { product at the supermarket }\end{array}$ & From 1 to 5 & 3.11 \\
\hline $\begin{array}{l}\text { Individual } \\
\text { behaviour }\end{array}$ & Ordered & 178 & $\begin{array}{l}\text { If thinks that individual behaviour can help fighting } \\
\text { climate change }\end{array}$ & From 1 to 5 & 3.29 \\
\hline Organic & Ordered & 178 & $\begin{array}{l}\text { If thinks that buying organic is important to help } \\
\text { reducing GHG emissions }\end{array}$ & From 1 to 5 & 3.29 \\
\hline $\begin{array}{l}\text { Importance } \\
\text { CF }\end{array}$ & Ordered & 178 & $\begin{array}{l}\text { If thinks that is important to have a CF label to inform } \\
\text { purchase decisions }\end{array}$ & From 1 to 5 & 4.03 \\
\hline Family & Continuous & 178 & Number of family members & $>0$ & 2.77 \\
\hline Age $<14$ & Continuous & 178 & For how many people younger than 14 shops for & $>0$ & 0.28 \\
\hline
\end{tabular}


explanatory variables expressing the characteristics and choices of the individual expected to influence the respective choice. By including among these variables some features of the individuals interviewed, we assume heterogeneous respondents' preferences.

For the sake of brevity, we only report the variables that were significant (Table 4).

\section{Results discussion}

Table 2 shows the answers to both the surveys to the different questions analysed. As regards survey A, interestingly, almost all the respondents declare to know the climate change phenomenon, are (on average) interested in it and think that the consumption of products with an environmental label helps contrasting climate change. This survey also reported a set of questions on which tools could be used to promote the knowledge and dissemination of CF labels and the web instruments and education were judged the most important, followed by campaigns, advertising, the label itself and newspapers.

As regards survey $\mathrm{B}$, the majority of respondents consider it important to have a CF label to inform purchase decisions in an environmental sense and thinks that buying organic food helps to reduce GHG emissions. However, it seems that the majority of the respondents do not read the label but gives importance to the sensory quality or expiration date when buying food.

Table 3 summarises some descriptive statistics of the pooled sample analysed, made by the common questions. As mentioned, being the sample self-selected and based on an online survey, some demographics reflect the nature of the data source. The respondents are $64 \%$ female. Almost all the respondents have at least a high school diploma, and 52\% have a university degree (or higher). Despite the low presence of CF label in the Italian market, a majority of subjects declared to know the concept of CF labels.

As regards WTP, results indicate that only $24 \%$ of the total sample states not to be willing to pay more for a litre of milk with lower CF. This figure is likely underestimated since it is based on a stated preference survey, and the sample is self-selected.

For respondents that declared a positive WTP, in case study A, an average $9 \%$ premium price for lower CF milk has emerged, with maximum values of $50 \%$. The premium price was on average $0.19 €$, assuming an average price of $2 €$. In case study $B$, the average WTP was more than $30 \%$. The consumer is likely to pay $€ 1.68$ per bottle of low CF milk and therefore, compared to the high-impact product proposed at the price of $€ 1.30$, the surplus difference is $€ 0.38$ (Author1 et al. 2018).

The results of the logit model estimation summarised in Table 4 allow identifying the drivers behind this positive WTP. ${ }^{8}$

Results indicate that in the sample analysed, if a respondent gives high importance to low impact products to tackle climate change, this trait positively affects the probability to be willing to pay more for CF-labelled milk. Also, the format of the different surveys

\footnotetext{
${ }^{8}$ As regards to the goodness-of-fit of the model, the value of the Pseudo $R^{2}$ is typical of fairly fitting models (McFadden 1979: 307).Looking at the discrimination ability of the model (i.e. the capacity of correctly distinguishing between positive and negative replies), the area under the receiver operating characteristic (ROC) curve is reported. This value gives the probability that the model correctly ranks a randomly chosen pairs of observations. In the model, the area under the ROC curve is 0.735 which is an acceptable value as this figure should be higher than 0.5 (but lower than 1 ) to indicate a satisfactorily fitting model.
} 
Table 3 Descriptive statistics of the questions asked in both surveys

\begin{tabular}{|c|c|c|c|c|c|}
\hline Variable & $\begin{array}{l}\text { Type of } \\
\text { variable }\end{array}$ & Obs. & Description & Possible values & $\begin{array}{l}\text { Percentage, } \\
\text { mean }\end{array}$ \\
\hline Age & Continuous & 391 & Age of the respondent & $\operatorname{Min}(21) \max (75)$ & Mean 39.5 \\
\hline \multirow[t]{2}{*}{ Graduate } & \multirow[t]{2}{*}{ Binary } & \multirow[t]{2}{*}{393} & \multirow[t]{2}{*}{ The respondent is graduated } & Yes (1) & 52.4 \\
\hline & & & & No $(0)$ & 47.6 \\
\hline \multirow[t]{2}{*}{ Gender } & \multirow[t]{2}{*}{ Binary } & \multirow[t]{2}{*}{393} & \multirow[t]{2}{*}{ Sex of the respondent } & Female (1) & 64 \\
\hline & & & & Male (0) & 36 \\
\hline \multirow{2}{*}{$\begin{array}{l}\text { High } \\
\text { income }\end{array}$} & \multirow[t]{2}{*}{ Binary } & \multirow[t]{2}{*}{393} & \multirow{2}{*}{$\begin{array}{l}\text { The respondent belongs to } \\
\text { high-income class }\end{array}$} & Yes (1) & 24.9 \\
\hline & & & & No $(0)$ & 75.1 \\
\hline \multirow[t]{2}{*}{ Knows CF } & \multirow[t]{2}{*}{ Binary } & \multirow[t]{2}{*}{393} & \multirow[t]{2}{*}{ The respondent knows the CF label } & Yes (1) & 31.6 \\
\hline & & & & No $(0)$ & 68.4 \\
\hline \multirow[t]{2}{*}{$\begin{array}{l}\text { Price } \\
\text { Sensitivity }\end{array}$} & \multirow[t]{2}{*}{ Binary } & \multirow[t]{2}{*}{393} & \multirow[t]{2}{*}{$\begin{array}{l}\text { Importance of price when purchasing } \\
\text { products (from } 1 \text { to } 5 \text { ) }\end{array}$} & $\begin{array}{l}\text { Important (scores } 4 \\
\text { and 5: 1) }\end{array}$ & 38.9 \\
\hline & & & & $\begin{array}{l}\text { All other responses } \\
\text { (scores 1-3: 0) }\end{array}$ & 61.1 \\
\hline \multirow[t]{2}{*}{$\begin{array}{l}\text { Brand } \\
\text { sensitivity }\end{array}$} & \multirow[t]{2}{*}{ Binary } & \multirow[t]{2}{*}{393} & \multirow[t]{2}{*}{$\begin{array}{l}\text { Importance of brand when purchasing } \\
\text { products(from } 1 \text { to } 5 \text { ) }\end{array}$} & $\begin{array}{l}\text { Important }{ }^{\mathrm{a}} \text { (scores } \\
4 \text { and 5: 1) }\end{array}$ & 63.6 \\
\hline & & & & $\begin{array}{l}\text { All other responses } \\
\text { (scores 1-3: 0) }\end{array}$ & 36.4 \\
\hline \multirow[t]{2}{*}{ Origin } & \multirow[t]{2}{*}{ Binary } & \multirow[t]{2}{*}{393} & \multirow[t]{2}{*}{$\begin{array}{l}\text { Importance of product origin when } \\
\text { buying food }\end{array}$} & $\begin{array}{l}\text { Important }{ }^{\mathrm{a}} \text { (scores } \\
4 \text { and 5: 1) }\end{array}$ & 31.2 \\
\hline & & & & $\begin{array}{l}\text { All other responses } \\
\text { (scores 1-3: 0) }\end{array}$ & 68.8 \\
\hline \multirow[t]{2}{*}{$\mathrm{Km} 0$} & \multirow[t]{2}{*}{ Binary } & \multirow[t]{2}{*}{393} & \multirow[t]{2}{*}{$\begin{array}{l}\text { Importance of food at } \mathrm{Km} 0 \text { in mitigating } \\
\text { climate change (from } 1 \text { to } 5 \text { ) }\end{array}$} & $\begin{array}{l}\text { Important }{ }^{\mathrm{a}} \text { (scores } \\
4 \text { and 5: 1) }\end{array}$ & 67.4 \\
\hline & & & & $\begin{array}{l}\text { All other responses } \\
\text { (scores 1-3: 0) }\end{array}$ & 32.6 \\
\hline \multirow[t]{2}{*}{$\begin{array}{l}\text { Low } \\
\text { impact }\end{array}$} & Binary & 393 & $\begin{array}{l}\text { Importance of food produced with low } \\
\text { impact processes in mitigating }\end{array}$ & $\begin{array}{l}\text { Important }{ }^{\mathrm{a}} \text { (scores } \\
4 \text { and 5: 1) }\end{array}$ & 50.9 \\
\hline & & & $\mathrm{ClI}$ & $\begin{array}{l}\text { All other responses } \\
\text { (scores 1-3: 0) }\end{array}$ & 49.1 \\
\hline $\begin{array}{l}\text { No } \\
\text { packaging }\end{array}$ & Binary & 393 & $\begin{array}{l}\text { Importance of reducing packaging to have a } \\
\text { positive impact on CF reduction }\end{array}$ & $\begin{array}{l}\text { Important }{ }^{a} \text { (scores } \\
4 \text { and 5: } 1 \text { ) }\end{array}$ & 60.6 \\
\hline & & & & $\begin{array}{l}\text { All other responses } \\
\text { (scores 1-3: 0) }\end{array}$ & 39.4 \\
\hline WTP & Binary & 393 & The respondent expresses a positive WTP & Yes (1) & 76.08 \\
\hline & & & & No $(0)$ & 23.92 \\
\hline Survey_B & Binary & 393 & Survey & $B(1)$ & 45.2 \\
\hline & & & & $\mathrm{A}(0)$ & 54.8 \\
\hline
\end{tabular}

Source: Authors' elaborations.

after careful consideration of some originally ordinal variables' distribution and performances in the model, they have been converted into dichotomous variables, with value one when respondents judge the characteristics analysed being "important" or "extremely important" (original response equal to 4 or 5 ) and value zero to all other responses (original response from 1 to 3 ). The recoding allows emerging the behaviour of the respondent that give more importance to the specific characteristic; results do not notably change when considering the original responses as categorical variables

may matter: survey B respondents are more likely to show a positive WTP compared to survey A respondents.

As regards socio-demographic variables, respondents who are more sensitive to price when buying products (about $40 \%$ of the sample) are less likely to be willing to pay more for products with a lower CF label; this result is consistent with what other authors in this field have found (see among others Vanclay et al. 2011). 
Table 4 Estimations results

\begin{tabular}{llll}
\hline Variable & Coefficients estimates & $p$ values & Standard errors \\
\hline Gender (female) & 0.490 & 0.060 & 0.261 \\
Low impact products & 0.890 & 0.001 & 0.265 \\
Price sensitivity & -0.837 & 0.001 & 0.257 \\
Survey_B & 1.008 & 0.000 & 0.287 \\
Constant & 0.475 & 0.058 & 0.251 \\
\hline LR $x^{2}(4)=51.23 ;$ Prob $>x^{2}=0.000 ;$ Pseudo $R^{2}=0.12$; Hosmer-Lemeshow $\chi^{2}(7)=6.29 ;$ Prob $>x^{2}=0.506$; area under the \\
ROC curve $=0.735$
\end{tabular}

Instead, the only knowledge of the CF concept does not seem to be relevant in determining the stated perception of value. Also, age and education do not affect the WTP of consumers, similarly to what was found from the detailed analysis of case study A published in another article (Author1 and Author2 2019).

As regards gender, females show a slightly higher WTP than males, but this result is significant only at the 0.10 level. Hence, even if this result goes in the direction of what found in previous work (e.g. Steiner et al. 2017; Vecchio and Annunziata 2015), its statistical significance is quite poor.

\section{Conclusions and policy implications}

CF labels represent one of the most important tools to help to tackle climate change through consumers' informed purchases behaviour.

Despite their relevance for demand-driven mitigation options, their presence is still scarce in the Italian food sector, and so it is also for studies aimed at investigating Italian consumers' WTP for products with lower CF. From the literature review, a positive WTP for lower CF products seems to emerge, though not for all products and respondents' socio-economic characteristics.

The two pilot case studies presented, focused on Italian consumers' habits when purchasing milk, allowed us to make a rough evaluation of their preferences for lowcarbon-labelled dairy products.

Results, though based on convenience and probably biased samples and stated preferences, suggest that the interest of consumers in CF labels may exist. Findings are generally in line with previous studies indicating that respondents that give high importance to foodstuff produced with low environmental impact to mitigate GHG emissions have shown to be more willing to attribute a positive premium price to CF-labelled products. Also, the data confirm that CF labels could be most effective when combined with prices lower than (or at least equal to) conventional products (Vanclay et al. 2011), as more price-sensitive consumers are less prone to perceive a higher value for lower CF products.

Those results, if confirmed by larger and representative samples, may have interesting policy implications. In fact, they would suggest that a policy framework aiming at promoting demand-side mitigation options in the agricultural sector should tackle both the consumers' side, informing consumers about the environmental impact of food production and the potential of environmental label in reducing it, 
and the producers' side, helping the food supply chain reducing its GHG emission in a cost-effective way.

About the consumers' side, policies should aim at both enhancing consumers' awareness about climate change challenge and ensure that the system of certification is reliable and easily interpretable by consumers. To this respect, the initiative of the European Commission (2013) on "building the single market for green products facilitating better information on the environmental performance of products and organisations", is of utmost importance.

As regards the production side, results would suggest to producers that a lower CF would be appealing if offered at the same or a lower price. Indeed, the possibility to couple lower prices with lower GHG emissions in the agricultural sector is not rare, because technical studies on the mitigation potential of agri-food productions have found many of the so-called "win-win solution" to climate change, i.e. strategies that allow saving both GHG emissions and production costs (Coderoni et al. 2015). When a win-win solution is adopted, thus, lower CF products can be produced at lower $\operatorname{costs}^{9}$ that could, in turn, be translated into lower selling prices, as entrepreneurs participating in the CF labelling scheme have declared to be willing to do (Coderoni and Pontrandolfi 2016). If these solutions are applied, thus, CF product uptake could be easily enabled.

Also, Rural Development Programmes funds could be used to reduce farmers' costs of adopting GHG saving techniques, as they provide incentives for both GHG calculation and certification and farms' investments to implement mitigation strategies identified. This should be made taking into account the likely evolution of the food systems as a whole (Macombe 2018).

Given the limitations of this study, a more in-depth analysis is needed to estimate Italian consumers' WTP for CF labels accurately. Future research should on one side, rely upon a larger and nation-wide representative sample to avoid the problems linked to self-selected and biased samples; on the other side, it should focus on non-hypothetical techniques, such as experimental auctions to obtain reliable estimations of WTP (Lusk and Shogren 2007). In fact, the studies based on hypothetical choices, generally, tend to overestimate the WTP and the experience of Tesco with CF-labelled products seems to confirm this gap between stated and real behaviour. A further research avenue could be the consideration of a more comprehensive framework for the analysis of the environmental impact of food consumption, covering not only the GHG emissions generated, but also the use of resources such as water and land, and the generation of waste (Candy et al. 2018).

\footnotetext{
${ }^{8}$ As regards to the goodness-of-fit of the model, the value of the Pseudo $R^{2}$ is typical of fairly fitting models (McFadden 1979: 307).Looking at the discrimination ability of the model (i.e. the capacity of correctly distinguishing between positive and negative replies), the area under the receiver operating characteristic (ROC) curve is reported. This value gives the probability that the model correctly ranks a randomly chosen pairs of observations. In the model, the area under the ROC curve is 0.735 which is an acceptable value as this figure should be higher than 0.5 (but lower than 1) to indicate a satisfactorily fitting model.

${ }^{9}$ For example, because the product certification procedures allow highlighting hot spot in energy consumption or emission intensive packaging that can be reduced.
} 


\section{Acknowledgements}

The authors would like to thank Elena Visi and Elena Visi for providing the data they collected for their bachelor's thesis. This paper has been selected as one of the best papers of the First joint SIDEA-SIEA Conference in Bisceglie/ Trani (13-16 September 2017). It has been accepted for publication in this journal following the usual review process.

\section{Authors' contribution}

Authors are listed in alphabetical order. This paper was developed jointly by the authors; nevertheless, the individual contribution may be identified as follows: Section 1, 2 and 3 to MC; Section 4, 5 and 6 to SC. Both the authors have approved the manuscript for submission.

\section{Funding}

This research did not receive any specific grant from funding agencies in the public, commercial, or not-for-profit sectors.

\section{Availability of data and materials}

The datasets used and/or analysed during the current study are available from the corresponding author on reasonable request

\section{Competing interests}

The authors declare that they have no competing interests.

\section{Author details}

'Department of Agricultural and Food Sciences, Alma Mater Studiorum-Università di Bologna, viale Giuseppe Fanin, 50, Bologna 40127, Italy. ${ }^{2}$ Department of Economics and Social Sciences, Università Politecnica delle Marche, Piazzale Martelli, 8, 60121 Ancona, Italy.

Received: 3 August 2018 Accepted: 23 December 2019

Published online: 07 January 2020

\section{References}

Akaichi F, de Grauw S, Darmon P, Revoredo-Giha C (2016) Does fair trade compete with carbon footprint and organic attributes in the eyes of consumers? Results from a Pilot Study in Scotland, the Netherlands and France. J Agric Environ Ethics 29(6):969-984. https://doi.org/10.1007/s10806-016-9642-7

Akaichi F, Nayga RM, Gil JM. (2013) Do consumers make tradeoffs with respect to GHG emissions, local, and food miles attributes? Evidence from Experimental Auctions of US Rice. INRA (Ed.), 1-28. Paris: INRA.

Armel KC, Yan K, Todd A, Robinson TN (2011) The Stanford Climate Change Behavior Survey (SCCBS): assessing greenhouse gas emissions-related behaviors in individuals and populations. Clim Chang 109(3):671-694

Canavari M, Coderoni S (2019) Green marketing strategies in the dairy sector: consumer stated preferences for carbon footprint labels. Strateg Change 28(4):233-240. https://doi.org/10.1002/jsc.2264

Canavari M, Coderoni S, Giuliodori L, Visi E (2018) Consumer stated preferences for environmental labels: two case studies in the dairy sector, Proceedings of the 54th SIDEA Conference-25th SIEA Conference Cooperative Strategies and value creation in sustainable food supply chain, Bisceglie/Trani, September 13-16 2017, ISBN 9788891786883, FrancoAngeli Edizioni, Milan.

Bajželj B, Richards KS, Allwood JM, Smith P, Dennis JS, Curmi E, Gilligan CA (2014) Importance of food-demand management for climate mitigation. Nat Climate Change 4:924. https://doi.org/10.1038/nclimate2353

Baldoni E, Coderoni S, Esposti R (2017) The productivity and environment nexus through farm level data. The case of carbon footprint applied to Italian FADN farms. Biobased Appl Econ 6(2):119-137. https://doi.org/10.13128/BAE-19112

Baldoni E, Coderoni S, Esposti R (2018) The complex farm-level relationship between environmental performance and productivity. The Case of Carbon Footprint of Lombardy farms. Environ Sci Policy 89C:73-82

Bazzani C, Canavari M (2013) Alternative agri-food networks and short food supply chains: a review of the literature. Economia Agro-Alimentare 15(2):11-34. https://doi.org/10.3280/ECAG2013-002002

Bazzani C, Canavari M (2017) Is local a matter of food miles or food traditions? Ital J Food Sci 29(3):505-517. https://doi.org/ $10.14674 /$ IJFS-733

Brunelle T, Coat M, Viguié V (2017) Demand-side mitigation options of the agricultural sector: potential, barriers and ways forward. OCL 24(1):D104. https://doi.org/10.1051/ocl/2016051

Canavari M, Bazzani C, (2016) Opzioni di mitigazione dal lato della domanda. In Coderoni S, Pontrandolfi A, (eds.), Zootecnia italiana e mitigazione dei cambiamenti climatici. Stato dell'arte e prospettive, ISBN 9788899595289, CREA, Roma.

Canavari M, Nayga RM (2009) On consumers' willingness to purchase nutritionally enhanced genetically modified food. Appl Econ 41(1):125-137. https://doi.org/10.1080/00036840701367564

Canavari M, Nocella G, Scarpa R (2005) Stated willingness-to-pay for organic fruit and pesticide ban: an evaluation using both web-based and face-to-face interviewing. J Food Prod Mark 11(3):107-134. https://doi.org/10.1300/J038v11n03_07

Candy S, Turner GM, Sheridan J, Carey R (2018) Quantifying Melbourne's "Foodprint": a scenario modelling methodology to determine the environmental impact of feeding a city. Economia Agro-Alimentare / Food Economy 20(3):371-399. doi: https://doi.org/10.3280/ECAG2018-003007

Caputo V, Canavari M, Nayga R M (2012) Valutazione delle preferenze di consumatori campani per un sistema di etichettatura generico sulle "food miles" Economia agro-alimentare 14(1):99-115. doi:https://doi.org/10.3280/ECAG2012-001005

Caputo V, Nayga RM, Scarpa R (2013a) Food miles or carbon emissions? Exploring labelling preference for food transport footprint with a stated choice study. Austr J Agric Resour Econ 57(4):465-482. https://doi.org/10.1111/1467-8489.12014

Caputo V, Vassilopoulos A, Nayga RM, Canavari M (2013b) Welfare effects of food miles labels. J Consum Aff 47(2):311-327. https://doi.org/10.1111/joca.12009 
Chen N, Zhang Z-H, Huang S, Zheng L (2017) Chinese consumer responses to carbon labelling: evidence from experimental auctions. J Environ Plann Manage 61(13):2319-2337. https://doi.org/10.1080/09640568.2017.1394276

Coderoni S, Esposti R (2014) Is there a long-term relationship between agricultural GHG emissions and productivity growth? A dynamic panel data approach. Environ Resour Econ 58(2):273-302. https://doi.org/10.1007/s10640-013-9703-6

Coderoni S, Esposti R (2018) CAP payments and agricultural GHG emissions in Italy. A farm-level assessment. Sci Total Environ 627:427-437. https://doi.org/10.1016/j.scitotenv.2018.01.197

Coderoni S, Pontrandolfi A (2016) Zootecnia italiana e mitigazione dei cambiamenti climatici. CREA, Roma Stato dell'arte e prospettive, ISBN 9788899595289

Coderoni S, Valli L, Canavari M (2015) Climate change mitigation options in the italian livestock sector. Eurochoices 14(1):1724. https://doi.org/10.1111/1746-692X.12077

Colantuoni F, Cicia G, Del Giudice T, Lass AD, Caracciolo F, Lombardi P (2016) Heterogeneous preferences for domestic fresh produce: evidence from German and Italian early potato markets. Agribusiness 32(4):512-530. https://doi.org/10.1002/agr. 21460

Council of the European Union (2013a) Regulation (EU) No 1305/2013 of the European Parliament and of the Council of 17 December 2013 on support for rural development by the European Agricultural Fund for Rural Development (EAFRD) and repealing Council Regulation (EC) No 1698/2005, 17 December 2013, Brussels

Council of the European Union (2013b) Regulation (EU) No 1307/2013 of the European Parliament and of the Council establishing rules for direct payments to farmers under support schemes within the framework of the common agricultural policy, 17 December 2013, Brussels

Creutzig F, Fernandez B, Haberl H, Khosla R, Mulugetta Y, Seto KC (2016) Beyond technology: demand-side solutions for climate change mitigation. Annu Rev Environ Resour 41 (1):173-198. https://doi.org/10.1146/annurev-environ-1 10615-085428

de Boer J, de Witt A, Aiking H (2016) Help the climate, change your diet: a cross-sectional study on how to involve consumers in a transition to a low-carbon society. Appetite 98:19-27. https://doi.org/10.1016/j.appet.2015.12.001

De Pelsmacker P, Driesen L, Rayp G (2005) Do Consumers Care about Ethics? Willingness to Pay for Fair-Trade Coffee. Journal of Consumer Affairs, 39(2):363-385. https://doi.org/10.1111/j.1745-6606.2005.00019.x.

Drichoutis AC, Lusk JA, Pappa V (2016) Elicitation formats and the WTANTP gap: A study of climate neutral foods. Food Policy 61:141-155. https://doi.org/10.1016/j.foodpol.2016.03.001

Echeverría R, Moreira VH, Sepúlveda C, Wittwer C (2014) Willingness to pay for carbon footprint on foods. Br Food J 116(2): 186-196. https://doi.org/10.1108/BFJ-07-2012-0292

European Commission (2009) Europeans' attitudes towards the issue of sustainable consumption and production, Report 256, Analytical report Fieldwork: April 2009.

European Commission (2011) A Roadmap for moving to a competitive low carbon economy in 2050, COM(2011)112 Final. Brussels

European Commission (2012) Attitudes of Europeans towards building the single market for green products, Flash Eurobarometer 367, Report Fieldwork: December 2012.

European Commission (2013) Building the Single market for green products facilitating better information on the environmental performance of products and organisations, COM(2013)196 final. Brussels

European Commission (2016) Proposal of a Regulation on binding annual greenhouse gas emission reductions by Member States from 2021 to 2030 for a resilient Energy Union and to meet commitments under the Paris Agreement and amending Regulation N.525/2013. COM(2016)482 final, Brussels

Financial Times (2012) Tesco steps back on carbon footprint labeling. January 31. By Louise Lucas and Pilita Clarke. Retrieved from: https://www.ft.com/content/96fd9478-4b71-11e1-a325-00144feabdc0

Garnett T (2011) Where are the best opportunities for reducing greenhouse gas emissions in the food system (including the food chain)? Food Policy 36:S23-S32

Gerber PJ, Steinfeld H, Henderson B, Mottet A, Opio C, Dijkman J, Falcucci A, Tempio G (2013) Tackling climate change through livestock. In: A global assessment of emissions and mitigation opportunities. Food and Agriculture Organization of the United Nations, Rome

GRAIN, IATP (2018) Emissions impossible. How big meat and dairy are heating up the planet, 2018, Retrieved from: https:// www.iatp.org/emissions-impossible.

Grebitus C, Steiner B, Veeman M (2012) Personal values and decision making: evidence from environmental footprint labeling in Canada. Am J Agric Econ 95(2):397-403. https://doi.org/10.1093/ajae/aas109

Grebitus C, Steiner B, Veeman M (2015) The roles of human values and generalized trust on stated preferences when food is labeled with environmental footprints: Insights from Germany. Food Policy 52:84-91. https://doi.org/10.1016/j.foodpol. 2014.06.011

Grebitus C, Steiner B, Veeman M (2016) Paying for sustainability: a cross-cultural analysis of consumers' valuations of food and non-food products labeled for carbon and water footprints. J Behav Exp Econ 63:50-58. https://doi.org/10.1016/j.socec. 2016.05.003

Grunert KG, Hieke S, Wills J (2014) Sustainability labels on food products: consumer motivation, understanding and use. Food Policy 44:177-189. https://doi.org/10.1016/j.foodpol.2013.12.001

Hoek AC, Pearson D, James SW, Lawrence MA, Friel S (2017) Healthy and environmentally sustainable food choices: consumer responses to point-of-purchase actions. Food Qual Preference 58:94-106. https://doi.org/10.1016/j.foodqual. 2016.12.008

Kimura A, Wada Y, Kamada A, Masuda T, Okamoto M, Goto S-I, Tsuzuki D, Cai D, Oka T, Dan I (2010) Interactive effects of carbon footprint information and its accessibility on value and subjective qualities of food products. Appetite 55(2):271278. https://doi.org/10.1016/j.appet.2010.06.013

Sander M, Heim N, Kohnle Y (2016) Label-Awareness: Wie genau schaut der Konsument hin? - Eine Analyse des LabelBewusstseins von Verbrauchern unter besonderer Berücksichtigung des Lebensmittelbereichs. Berichte Über Landwirtschaft 94(2):1-20. https://doi.org/10.12767/buel.v94i2.120

Koistinen L, Pouta E, Heikkilä J, Forsman-Hugg S, Kotro J, Mäkelä J, Niva M (2013) The impact of fat content, production methods and carbon footprint information on consumer preferences for minced meat. Food Qual Preference 29(2):126136. https://doi.org/10.1016/j.foodqual.2013.03.007 
Kumar V, Rahman Z, Kazmi AA, Goyal P. 2012. Evolution of sustainability as marketing strategy: beginning of new era. Procedia_Social and Behavioral Sciences 37:482-489. doi: https://doi.org/10.1016/j.sbspro.2012.03.313.

Li X, Jensen KL, Clark CD, Lambert DM (2016) Consumer willingness to pay for beef grown using climate friendly production practices. Food Policy 64:93-106. https://doi.org/10.1016/j.foodpol.2016.09.003

Lombardi GV, Berni R, Rocchi B (2017) Environmental friendly food. Choice experiment to assess consumer's attitude toward "climate neutral" milk: the role of communication. J Cleaner Prod 142:257-262. https://doi.org/10.1016/j.jclepro.2016.05.125

Lusk JL, Shogren JF (2007) Experimental auctions: methods and applications in economic and research. Cambridge University Press, Cambridge

Macombe C (2018) Diversity of food systems for securing future food availability. Economia Agro-Alimentare / Food Economy 20(3):349-368. https://doi.org/10.3280/ECAG2018-003006

McFadden D (1979) In: Hensher D, Stopher P, Helm C (eds) Quantitative methods for analyzing travel behaviour on individuals: some recent developments, in behavioral travel modelling, pp 279-318

Michaud C, Llerena D, Joly I (2012) Willingness to pay for environmental attributes of non-food agricultural products: a real choice experiment. Eur Rev Agric Econ 40(2):313-329. https://doi.org/10.1093/erae/jbs025

Miranda-Ackerman MA, Azzaro-Pantel C (2017) Extending the scope of eco-labelling in the food industry to drive change beyond sustainable agriculture practices. Journal of Environmental Management 204:814-824. https://doi.org/10.1016/j. jenvman.2017.05.027

Mostafa MM (2016) Egyptian consumers' willingness to pay for carbon-labeled products: A contingent valuation analysis of socio-economic factors. J Cleaner Prod 135:821-828. https://doi.org/10.1016/j.jclepro.2016.06.168

Nordhaus W (2013) The Climate Casino: Risk, Uncertainty, and Economics for a Warming World. Yale University Press, New Haven

Onozaka Y, Mcfadden DT (2011) Does local labeling complement or compete with other sustainable labels? A conjoint analysis of direct and joint values for fresh produce claim. Am J Agric Econ 93(3):693-706. https://doi.org/10.1093/ajae/aar005

Peschel AO, Grebitus C, Steiner B, Veeman M (2016) How does consumer knowledge affect environmentally sustainable choices? Evidence from a cross-country latent class analysis of food labels. Appetite 106:78-91. https://doi.org/10.1016/j. appet.2016.02.162

Rete Rurale Nazionale (2012) Libro bianco. Sfide ed opportunità dello sviluppo rurale per la mitigazione e l'adattamento ai cambiamenti climatici. Rete Rurale Nazionale, ISBN 978-88-96095-11-9; Imago Editrice S.r.l.

SDC (Sustainable Development Commission) (2003) A vision for sustainable agriculture, URL: http://www.sd-commission.org. uk/publications.php.

Shewmake S, Okrent A, Thabrew L, Vandenbergh M (2015) Predicting consumer demand responses to carbon labels. Ecol Econ 119:168-180. https://doi.org/10.1016/j.ecolecon.2015.08.007

Steiner BE, Peschel AO, Grebitus C (2017) Multi-product category choices labeled for ecological footprints: exploring psychographics and evolved psychological biases for characterizing latent consumer classes, ecological economics, vol 140, pp 251-264. https://doi.org/10.1016/j.ecolecon.2017.05.009

Stern N (2007) The economics of climate change: the Stern review. Cambridge University Press, Cambridge

The Economist (2011) Following the footprints, June 2nd 2011, Retrieved from: http://media.economist.com/news/ technology-quarterly/18750670-environment-carbon-li-labels-which-indicate-products-environmental.

Vackier I, Vuylsteke A, Verbeke W, Van Huylenbroek G (2002) Desk study on consumer behaviour towards sustainable food products. National Report Belgium. 5th framework programme project: marketing sustainable agriculture: an analysis of the potential role of new food supply chains in sustainable rural development. Ghent University

Van Loo EJ, Caputo V, Nayga RM, Seo H-S, Zhang B, Verbeke W (2015) Sustainability labels on coffee: consumer preferences, willingness-to-pay and visual attention to attributes. Ecol Econ 118:215-225. https:/doi.org/10.1016/j.ecolecon.2015.07.011

Van Loo EJ, Caputo V, Nayga RM, Verbeke W (2014) Consumers' valuation of sustainability labels on meat. Food Policy 49(P1): 137-150. https://doi.org/10.1016/j.foodpol.2014.07.002

Vanclay JK, Shortiss J, Aulsebrook S, Gillespie AM, Howell BC, Johanni R, Maher MJ, Mitchell KM, Stewart MD, Yates J (2011) Customer response to carbon labelling of groceries. J Consum Policy 34(1):153-160. https://doi.org/10.1007/s10603-0109140-7

Vecchio R (2013) Determinants of willingness-to-pay for sustainable wine: evidence from experimental auctions. Wine Econ Policy 2(2):85-92. https://doi.org/10.1016/j.wep.2013.11.002

Vecchio R, Annunziata A (2015) Willingness-to-pay for sustainability-labelled chocolate: an experimental auction approach. J Cleaner Prod 86:335-342. https://doi.org/10.1016/j.jclepro.2014.08.006

Vermeir I, Verbeke W (2006) Sustainable food consumption: exploring the consumer "attitude-behavioral intention" gap. J Agric Environ Ethics 19(2):169-194. https://doi.org/10.1007/s10806-005-5485-3

Zander K, Hamm U (2010) Consumer preferences for additional ethical attributes of organic food. Food Qual Preference 21(5):495-503. https://doi.org/10.1016/j.foodqual.2010.01.006

\section{Publisher's Note}

Springer Nature remains neutral with regard to jurisdictional claims in published maps and institutional affiliations. 